\title{
As relações poético-plásticas e a natureza em Helena Kolody e Miguel Bakun
}

\author{
Poetic-visual relations and nature in Helena Kolody and \\ Miguel Bakun
}

\author{
Vanderlei Kroin* \\ vanderleikroin@gmail.com \\ Universidade Estadual do Oeste do Paraná
}

\begin{abstract}
RESUMO: Este trabalho tem por objetivo um estudo comparativo entre poesia e pintura, centrando o foco em dois artistas eslavos-brasileiros do século XX: a poeta Helena Kolody e o artista plástico Miguel Bakun, desvelando a presença da natureza na obra de ambos. Tal trabalho vale-se das premissas da literatura comparada, considerando-se de autores como Carvalhal (1986), Coutinho (2003), Nitrini (2010), também nos pressupostos teóricos interartísticos: Lessing (2011), Muhana (2002), Da Vinci (2000), Praz (1982), além de outros, como Bosi (2000a; 2000b), Paz (1991; 1996). Sabe-se das convergências e divergências cotejadas entre os dois sistemas de linguagem, o verbal e o visual, mas tendo-os como sistemas artísticos que falam do homem para o homem, pretende-se discutir suas correlações. Ainda, busca-se registrar a comparação entre os dois artistas citados, nascidos no interior do Paraná, no seio da cultura eslava, portanto, de certa maneira à margem do cânone modernista, o que vem ao encontro das perspectivas atuais dos estudos comparatistas, ou seja, descortinar obras e autores oriundos de áreas descentralizadas do globo.
\end{abstract}

PALAVRAS-CHAVE: Poesia. Pintura. Natureza. Helena Kolody. Miguel Bakun.

ABSTRACT: This work consists of a comparative study between poetry and painting, focusing on two Brazilian-Slavic artists of the 20th century, the poet Helena Kolody and the visual artist Miguel Bakun, unveiling the presence of nature in their works. This text applies the tenets of Comparative Literature, based on authors such as Carvalhal (1986), Coutinho (2003), Nitrini (2010), and the interartistic theoretical presuppositions of Lessing (2011), Muhana (2002), Da Vinci (2000), Praz (1982), and others such as Bosi (2000a; 2000b) and Paz (1991; 1996). We know the convergences and divergences between verbal and visual language systems, but understanding them as artistic systems that speak about humans to humans, we intend to discuss their correlations. We also aim to compare both artists, born in the countryside of Parana, in the core of Slavic culture and, therefore, in the margins of the modernist canon, adopting, thus, the current perspectives of comparative studies, viz., to bring to light works and authors that are from decentralized areas of the globe.

KEYWORDS: Poetry. Painting. Nature. Helena Kolody. Miguel Bakun.

\footnotetext{
* Mestre em Letras pela Universidade Estadual do Oeste do Paraná - UNIOESTE
} 


\section{Introdução}

Poesia e pintura são duas artes milenares que vêm acompanhando o homem ao longo de sua trajetória histórica. Sabe-se que, em se tratando de estudos de natureza aproximativa entre essas duas manifestações artísticas, há sempre divergências quanto à pertinência dessas aproximações, principalmente pelas singularidades desses dois diferentes sistemas de linguagem. Para além das teorias, prós ou contrárias à equiparação, deve-se salientar que toda arte se configura como construção humana, inerente ao homem e aí se incute o primeiro sinal, talvez vago, mas inconteste, da irmandade que ela mantém enquanto conjunto que correlaciona homem e mundo.

Dessa maneira, neste trabalho ${ }^{1}$ pretende-se descortinar a natureza presente na obra de Helena Kolody e na arte pictórica de Miguel Bakun, tendo como corpus um poema e uma tela, devido à limitação de espaço, mas com a ressalva de que a presença da natureza na obra de ambos, como um todo, é frequente.

Kolody e Bakun foram dois artistas eslavo-brasileiros, descendentes de ucranianos e radicados fortemente no Sul do Paraná em finais do século XIX e início do século XX. Portanto, aproximar a obra de dois sujeitos que produziram em um espaço descentralizado vem ao encontro dos preceitos atuais do campo comparatista - dominado pelo ecletismo que propicia e agrega tais estudos - ou seja, o de redescobrir e/ou aprofundar estudos sobre artistas desses espaços considerados ainda periféricos frente ao cânone imposto.

Os Estudos Comparados, bem como a Literatura Comparada, foram sistematizações desencadeadas de análises e comparações engendradas entre literatura e outras artes, em geral, ao longo da história humana. Esta relação entre a literatura e diferentes esferas artísticas, também entre os diversos textos literários produzidos pelo homem, sempre foi de interesse do espírito humano, quase que simultaneamente ao início das primeiras produções artísticas aparecidas nas sociedades antigas.

Com a evolução humana, em seus vários aspectos, notadamente se

\footnotetext{
${ }^{1} \mathrm{O}$ presente artigo é recorte da dissertação intitulada Diálogos poético-plásticos e natureza em Helena Kolody e Miguel Bakun, defendida junto ao Programa de Pós-Graduação em Letras, Área de Concentração em Linguagem e Sociedade, da Universidade Estadual do Oeste do Paraná UNIOESTE, em fevereiro de 2017 e sob orientação do Prof. Dr. Antonio Donizeti da Cruz. A pesquisa teve o apoio financeiro da CAPES.
} 
intensificou, em conjunto, também o desenvolvimento da literatura e das artes. As produções artísticas desdobraram-se de tal maneira que se fizeram necessários estudos teóricos de diferentes orientações e naturezas a fim de buscar compreendêlas mais sistematicamente. Hoje, o campo comparatista agrega abordagens relacionais entre literatura e pintura, por exemplo, e os estudos desdobram-se para além dos escritores e pintores conhecidos mundialmente, mas os olhares também se voltam a autores não canonizados em esfera mundial, de múltiplos espaços e culturas, como é o caso de Kolody e Bakun.

\section{Estudos interartísticos e comparados e as relações poético-plásticas}

A literatura, caracterizada como a arte do verbo, se encontra em correspondência com outras formas de expressão; circula no mesmo cenário que as outras manifestações artísticas; portanto, não se constitui isoladamente, de modo que o comparatista deve ater-se a esses fatores quando do confronto entre os textos literários, sejam entre si ou com outras artes. Há, muitas vezes, a tendência dos estudiosos a dar destaque e ênfase à área em que se atua, a organizar um discurso convincente que acentue perante o outro a defesa da área de interesse particular, esquecendo-se, muitas vezes, de que isso é somente obliteração das relações que as áreas do conhecimento mantêm entre si. $O$ enclausuramento no texto, de um lado ou de outro, o escape às suas estruturas internas são redutores porque não contemplam a totalidade do processo da criação artística e a efetiva compreensão da obra.

De fato, a abertura dos estudos comparativos ao diálogo com outras áreas deu novo fôlego e alcance à disciplina, embora isso possa ser problemático na medida em que quanto mais abertura se tem no território comparatista, mais se podem confundir seus objetos e metodologias, o que, por outro lado, é visto com positividade, pois as relações estreitas entre áreas do saber é regra na sociedade mundial nos dias atuais. Esta afirmação é corroborada por Nitrini (2010), ao observar que:

Nos dias atuais, o estudo de relações entre literatura e outras artes já tem seu lugar garantido no domínio da Literatura Comparada. Se folhearmos os mais recentes manuais e livros teóricos de literatura comparada, inclusive os de tradição francesa, sempre encontraremos um capítulo ou pelo menos um item dedicado a essa questão. Vale 
lembrar que sua inclusão como objeto da literatura comparada decorreu do questionamento de que foi alvo a "escola francesa" nos anos 50 (NITRINI, 2010, p. 259).

Quanto à origem da Literatura Comparada, enquanto disciplina mais sistemática, de acordo com Carvalhal (1986), ela surgiu no século XIX, vinculada à corrente de pensamento cosmopolita que caracterizou o referido século. Posteriormente ganhou caráter interdisciplinar, tendência que se orienta pelo diálogo com diversas áreas e ciências, o que não lança ao descrédito os trabalhos realizados dentro do âmbito da Literatura comparada, mas faz-se necessário, porque é este intercâmbio que lança novas sementes e frutifica. Dessa maneira, o trabalho do comparatista não pode se constituir de unilateralidade. A disciplina vem se construindo transversalmente, dialogando com diversas áreas. Assim,

[...] graças a esse intercurso, o comparatismo ganhou dimensão, que se expressa hoje na multiplicidade de caminhos com que ele dialoga com a obra literária. Voltado cada vez mais para o texto, mas consciente da sua situação de discurso condicionado a uma realidade histórico-cultural determinada, portanto passível de questionamento, o comparatismo vem pondo em xeque seus pressupostos básicos, de teor etnocêntrico, e reformulando constantemente seus cânones [...] (COUTINHO, 2003, p. 19).

Considerando o texto, não somente o verbal, mas também o visual, conforme já assinalado anteriormente neste trabalho, a ideia é não reduzir as obras em análise a repetições artísticas do contexto sociohistórico em que foram produzidas, nem têlas como autômatas, mas sim estabelecer um comparativo de modo que predomine sempre o diálogo entre a arte produzida e o contexto, os autores e também os leitores, porque é assim que se constrói e se dissemina o conhecimento.

Muitos veem, na relação equiparativa entre arte visual e arte verbal, um disparate; outros a consideram inteiramente possível. Alguns ainda travam aproximações para realçar em importância uma das duas artes em relação à outra. Por exemplo, o pintor da renascença italiana Leonardo da Vinci colocou a pintura como uma arte superior em relação à poesia.

Da Vinci (2000) argumenta em favor da superioridade da pintura em relação à arte poética porque, para ele, aquela é mais comunicativa e visual que esta, representa mais verdadeiramente as coisas da natureza, e sua linguagem é mais universal, porque apela ao olhar, que, segundo o autor, é o mais digno dos sentidos. 
É ainda mais instantânea, e por esse imediatismo causa maior impacto à alma do homem. Nas palavras do artista,

A pintura apresenta, instantaneamente, a essência de seu objeto por intermédio da faculdade visual: meio pelo qual a sensibilidade recebe os objetos naturais, constituindo, ao mesmo tempo, a harmônica proporção das partes que compõe o todo, para contento do olho. (DA VINCl, 2000, p. 65).

Quanto à razão de a poesia ser inferior, de acordo Da Vinci (2000), ela imita os ditos dos homens e demora mais a satisfazer a expectativa deles, primeiro devido à da barreira da língua, depois porque o seu processo de assimilação demora mais na mente do ouvinte. De suas considerações, pode-se dizer que a poesia é uma arte retórica, que fala, enquanto a pintura, ao contrário, se mostra. É evidente que o olhar apreende mais depressa a imagem formada pelo desenho, mas essa mesma imagem está contida na poesia - só necessita de um leitor (ou ouvinte) competente que a interprete. Segundo Alfredo Bosi (2000b),

O caráter concreto da palavra poética não se identifica, necessariamente, com o caráter icônico, mais imediato das artes visuais. O concreto do poema cresce nas fibras espessas da palavra, que é um código sonoro e temporal; logo, um código de signos cujos referentes não transparecem, de pronto, à visão [...] (BOSI, 2000b, p. 134).

Estas palavras vêm ao encontro dos preceitos de Da Vinci, pois ressaltam a diferença imediata das duas artes em questão, fato já salientado anteriormente de que a pintura é usufruída do todo para as partes, enquanto, na poesia, se faz o inverso. O visual é, sem dúvida, mais imediato, o que não impossibilita o poema, com seus versos, formar uma imagem de um todo. São duas linguagens diferentes cujos arrolamentos formam imagens e, quando o pintor desenha em sua tela objetos, faz uma releitura também imperfeita do espaço que o circunda. Sugere mais que representa. O mesmo vale para o leitor/apreciador: o simples enxergar superficialmente as figuras e a paisagem, as cores dispostas em uma pintura, pode também não significar a formação de uma imagem interpretativa totalizante do que está exposto nela.

Assim, a imagem pictórica também pode não ser de simples entendimento; ver, admirar, agraciar-se com uma pintura, encantar-se com seus traços, figuras e cores não significa entendê-la na totalidade os sentidos que a obra emana. Da Vinci 
(2000) se refere à sua época, período em que a pintura era essencialmente figurativa, pautada no mimético e no realismo (o figurativismo), já que tinha por objetivo o resgate dos padrões geométricos, de beleza, de proporcionalidade grecoromana. Este padrão não pode ser considerado na mesma medida e perspectiva ao observar-se uma tela surrealista ou abstrata do século $X X$, por exemplo, quando as pinturas chamam mais atenção pela desproporção e utilização de figuras muitas vezes indiscerníveis, cuja referencialidade fica alocada, à primeira vista, em segundo plano.

Delimitar as fronteiras entre a arte poética e a arte pictórica é o que intentou também Lessing no século XVIII. Em seu Laocoonte: ou sobre as fronteiras da pintura e da poesia, de 1776, o autor alemão traz interessante debate e reflexões sobre as relações entre essas duas expressões artísticas. Define a pintura, grosso modo, como uma disposição de objetos em determinado espaço, enquanto a poesia como sucessão desses objetos no tempo. São os corpos (ou ações dos corpos) que constituem ambas as artes. Nas palavras do autor, "Objetos que existem um ao lado do outro ou cujas partes existem uma ao lado da outra chamam-se corpos. Consequentemente são os corpos com as suas qualidades visíveis que constituem o objeto próprio da pintura" (LESSING, 2011, p. 195).

Os corpos/objetos vão formando o todo e significam a totalidade da pintura. Dispostos na tela e coloridos de acordo com a percepção do pintor vão aglutinando significados. A visibilidade que apresentam é imediata. As cores, as figuras, as dimensões, a disposição na tela perfazem uma determinada cena, uma paisagem. É o corpo inteiro a que aludiu Da Vinci (2000) - inteiro, justamente porque a cena retratada se apresenta instantaneamente.

Nas considerações de Muhana (2002), poesia e pintura têm muita proximidade. Ambas (re)apresentam o mundo e o homem e "Simbolizam entre si como irmãs gêmeas, e parecem-se tanto, que quando se escreve se pinta, e quando se pinta, se escreve. Em língua grega o mesmo é escrever que pintar, ou esculpir, e é verbo comum ao pintor e ao poeta [...]" (MUHANA, 2002, p. 69-70). O pintor e o poeta formam imagens do mundo. Constroem paisagens, recriam e transformam 0 mundo que veem, em arte.

A poesia e a pintura expressam o próprio homem, ser inquieto, sempre em busca de mudanças, a exprimir e dar forma às coisas a partir de seu olhar particular, também a chamar a atenção de seu próximo, dar um "toque de Midas" e, assim, 
impressionar de diversas formas os outros homens. É deleitá-los, instigá-los, tocálos em sua sensibilidade, entre outras ações possibilitadas pelo fazer artístico. Nas palavras de Muhana (2002),

[...] assim como o pintor imita a natureza, ações e semelhanças de homem ou de qualquer animal, ou parte da terra, ou do mar, assim a pena retrata tudo [...] da poesia é próprio uma muda facúndia, da pintura um eloquente silêncio: este se cala naquela, e aquela razoa neste [...] a pintura [...] deleita a doutos e a ignorantes, o mesmo obra em ambos a poesia, porque os doutos se recreiam com a boa invenção e sua alegoria, e os ignorantes com as cadências do verso (MUHANA, 2002, p. 72).

O poema perfaz imagens, circunscreve um desenho na mente de quem se deleita com o lirismo dos versos. "A forma do texto poético é própria. Ele já é um desenho, mostra-se em verso, configura um espaço novo no pergaminho, na página ou na tela, todo o espaço se buscando, se sobrepondo [...]" (OLIVEIRA, 1999, p. 1213). Além disso, a poesia, ao ser recitada, expira melodia, musicalidade, despertando emoções e sentimentos, não conseguidos de outra forma que não pela arte. O poeta, ao fazer seus versos, organiza, meticulosamente, os vocábulos, os versos, as estrofes, de modo a ir formando na página em branco uma forma concreta que traz imanente uma imagem aos olhos do eventual leitor/ouvinte.

Octavio Paz (1996) assevera que o poema é um universo autossuficiente, em constante processo de recriação, estando a poesia tão ligada aos povos que toda sociedade, em todos os tempos, a possue. Paz ainda diferencia a poesia em relação à prosa, colocando a primeira em superioridade em relação à segunda. Segundo o autor,

A prosa é um gênero tardio, filho da desconfiança do pensamento ante as tendências naturais do idioma. A poesia pertence a todas as épocas: é a forma natural de expressão dos homens. Não há povos sem poesia, mas existem os que não têm prosa. Portanto, pode-se dizer que a prosa não é uma forma de expressão inerente à sociedade, enquanto que é inconcebível a existência de uma sociedade sem canções, mitos ou outras expressões poéticas. A poesia ignora o progresso ou a evolução e suas origens e seu fim se confundem com os da linguagem [...] (PAZ, 1996, p. 12).

A poesia está diretamente ligada à musica, tem suas raízes mais profundas na forma espontânea de expressão dos homens conforme salienta o autor. Ao observar-se o falar cotidiano, verifica-se, sem muito esforço, como ele é permeado de figuras de linguagem utilizadas na poesia. A linguagem figurada, gérmen da 
poesia, está impregnada de certa forma em nossa fala, sinal de que se mantém viva ao longo dos séculos por estar presente no dia a dia das pessoas, no seio da sociedade. O homem comum pode não compreender o poema, mas conhece muito de poesia. Como exemplo, pode ser citada uma conversa afagante de uma mãe com seu bebê e um diálogo mimoso entre um casal de namorados.

Lotman (1978) aponta que fazer poesia é também um trabalho intelectivo e formal, de modo que (alguns) poemas colocados no papel se distanciam da fala cotidiana, ainda que, como dito anteriormente, nasçam da mesma linguagem trivial utilizada pelo povo em algum momento da história. No dizer do autor,

O discurso poético representa uma estrutura de uma grande complexidade. Em relação à língua natural ele é consideravelmente mais complexo. E se o conjunto da informação contido no discurso poético (verso ou prosa, nesse caso não tem importância) e no discurso usual fosse semelhante, o discurso poético perderia todo o direito à existência e desapareceria sem dúvida nenhuma [...] (LOTMAN, 1978, p. 39).

Os poetas, apropriando-se da linguagem cotidiana, moldando-a e lapidandoa, constroem um discurso complexo, conforme assinalou Lotman, e assim esse discurso por vezes se separa e se afasta do alcance das pessoas, o que ocorre, por exemplo, com a poesia parnasiana.

O modo de construir poemas contemplando a natureza vem, primeiramente, da experiência sensível, conforme salienta Bosi (2000a), ao observar que o olhar do artista transforma o que vê, de modo a delegar a alcunha de arte ao que produz. Segundo o autor, "O ver do artista é sempre um transformar, um combinar, um repensar os dados da experiência sensível [...]" (BOSI, 2000a, p. 36). O poeta e o pintor, então, conseguem observar fatos que os olhares comuns não veem, transformá-los por meio da linguagem artística e assim levar a experiência da arte às pessoas, quando as fazem apreciar seja uma tela ou um poema. São pontes entre a sociedade e a natureza, entre o passado e o futuro. São sujeitos que levam o homem a pensar sobre si mesmo, a refletir acerca de sua existência como sujeito e sua condição de humano e, nisso, ajudam-no a crescer; além disso, atuam como impulsionantes (ainda que e as vezes até inconsciente e indiretamente) ao conhecimento e ao aprendizado.

Octavio Paz (1991) observa que a obra artística não é um produto, ou seja, não se constitui apenas como um artefato sem sentido, mas caracteriza-se como um 
leque de plurissignificação. Nas palavras do poeta e crítico mexicano, "[...] a obra não é uma coisa: é um leque de signos que, ao se abrir e fechar, nos deixa ver e nos oculta, alternativamente, seu significado. A obra de arte é um sinal de inteligência que o sentido e o sem-sentido trocam entre si [...]" (PAZ, 1991, p. 48). Esse "leque" a que se refere $\mathrm{Paz}$ pode ser entendido como a dinamicidade do processo de criação artística, do qual resulta um "artefato concreto" que não pode ser tomado nunca como uma coisa, mas que deve ser observado como algo único e exclusivo, nunca mais repetido do mesmo modo, nem mesmo pelo próprio artista que a criou.

Dessa maneira, pode-se dizer que o trabalho criativo - seja ele poético ou pictórico -, é um processo rítmico e dinâmico e porque, justamente agrega imaginação e trabalho, são duas faces indissociáveis do mesmo processo. Alinhase, desta maneira, o ato criativo à própria linguagem, porque a linguagem nasce do ritmo dinâmico da vida, e todo ritmo contagia, desconcerta, por isso a arte e a literatura sobrevivem ainda, porque têm um ritmo que descortina, apreende e reescreve o próprio ritmo da vida do homem.

\section{A poeticidade na natureza representada na obra de Kolody e Bakun}

A obra poética de Helena Kolody e a arte pictórica de Miguel Bakun têm a marca e o ritmo da natureza. Ambos se utilizam de linguagens diferentes para registrá-la e trazê-la ao poema e à tela numa perspectiva de proximidade, numa relação íntima entre o sujeito criador e o espaço geográfico que serve de mote e ao mesmo tempo de inspiração. Há um tom de respeito em relação a este espaço natural por parte de Kolody e Bakun. A reverência frente à natureza cotidiana embala a criação artística de ambos, e a sinceridade com que a registram é a de uma criança, mas conscientes de suas condições frente à grandeza agregadora do meio que os cercava. O cotidiano dessa natureza, com seus seres constituintes, seus ciclos, interpretados na linguagem verbal e visual, deixam entrever, tanto na poesia quanto na pintura, que a arte não se desgarra totalmente do ser que a produz.

O ser humano, enquanto ente, também é fruto da natureza, pertence ao reino animal, um dos vários que a compõe. É um ser orgânico, um animal provido de inteligência, mas esse atributo não o tira da condição de ser organicamente pertencente e componente do mundo. $\mathrm{O}$ homem evoluiu a ponto de conseguir viver 
civilizadamente, mas ainda mantém aceso dentro de si a chama da animalidade, mantém em estado de repouso a bestialidade e a selvageria, em estado mórbido a brutalidade, e tudo isso o liga ao homem ancestral, o qual estava intimamente vinculado à natureza, aos rios, aos animais, às matas.

A flagrante presença da natureza simples em Kolody e Bakun se evidencia pelas paragens representadas por ambos, além de características modernistas que as respectivas obras apresentam. Cada artista inovou a seu modo, se considerado o panorama da literatura e das artes no Paraná do século XX: Kolody por cultivar os versos curtos e os poemas sintéticos, principalmente haicais e tankas, gêneros de poemas de origem nipônica que tratam, também, da natureza; Bakun, por seu autodidatismo e perspectiva, cultivou uma pintura caracterizada por muitos críticos como de tendência expressionista, que teve como um dos principais precursores o pintor holandês Vincent van Gogh, ao qual Bakun foi equiparado, sendo denominado de "o van Gogh paranaense", principalmente pela grande utilização da cor amarela, do autodidatismo e também pela vida modesta que levava.

Os versos kolodyanos abaixo registram uma natureza singela, simples, uma natureza nem sempre perceptível, às vezes ignorada, mas que existe, está ali esperando alguém a descobri-la. São as águas calmas do rio, a suave melodia do canto dos pássaros, a dança das árvores, os animais minúsculos da floresta, as árvores componentes da mata, o vento a embalar as brincadeiras de crianças e as árvores, as estações do ano que configuram esta natureza, a qual a sensibilidade da poeta descobre e apresenta, também em uma linguagem leve, avessa a coisas grandiosas. Na tessitura da linguagem poética de Kolody (1993), o pequeno se torna grande.

O passarinho canta.

Não conhece teoria musical.

Gorjeia simplesmente porque o canto

é o seu imperativo existencial.

(CRUZ, 2012, p. 293).

O pássaro é valorizado. A poeta utiliza o diminutivo para retratar sua familiaridade com o pássaro e, por extensão, com a natureza, da qual a ave faz parte. É um registro sincero do canto e, ao mesmo tempo, do modo que ele aparece na natureza. É pequeno, mas se faz grande no desenrolar dos versos do poema de Kolody; é grande, porque encanta com seu melodioso gorjear e também porque 
canta sem conhecer teorias musicais: canta natural e despreocupadamente, canta pelo simples fato de existir. O eu lírico tributa uma ode à natureza no desenrolar dos versos.

O canto está ligado ao passarinho, no poema acima, como a poesia está no íntimo de Kolody. "[...] a poesia foi um imperativo psicológico [...]" (KOLODY, 1997, p. 35). Foi uma necessidade de registrar em versos o contato com o mundo, com esse mundo cotidiano que permeia toda a obra de Kolody. "A poetisa nasceu em mim antes da professora. No alvorecer da adolescência, que é como um novo nascer, senti necessidade de fazer versos, mesmo sem saber fazê-los [...]" (KOLODY, 1997, p. 37).

Na verdade, metaforicamente, Kolody é o próprio passarinho, e sua poética é o canto deste na natureza. A poeta, ainda muito jovem, teve necessidade de versejar e o sabia fazer, apesar de dizer o contrário na passagem acima exposta. É como o passarinho do poema, que pode não ter consciência nem saber o porquê canta, mas sabe como fazê-lo. É a naturalidade de ambos que encanta. É o som melodioso da ave e a linguagem interpelando o cotidiano que Kolody emprega em seu fazer poético. É a externalização do íntimo do ser que se deixa verificar ao ouvir o canto do pássaro e o modo como a poeta transplanta essa ação em linguagem poética.

Kolody realiza uma poesia que efetiva, de maneira geral, a presentificação dos elementos puros, tais como a fonte, a mãe, a água, a natureza, o sol, o fruto, o mar. A interioridade aflora na poesia kolodyana através a alegria de viver, da celebração e glorificação do mundo, valendo-se de sua visão de mundo, seu eu questionador, sua condição de viajante e de observador atento, que está no mundo só de passagem (CRUZ, 2012, p. 78).

A natureza cotidiana é o cerne da poesia de Kolody, com a consciência da efemeridade de alguns dos elementos constituintes dessa natureza, como o pássaro, o fruto, a mãe e, inclusive, o próprio ser humano, o poeta, que pode imortalizar-se pela linguagem que registra de tudo que o cerca. Assim como o poeta, a natureza também tem seus sons, suas linguagens: o gorjear do pássaro, o correr das águas do rio, o sibilar do vento, o ciciar das folhas. Essa natureza agrega ainda o homem e sua linguagem.

$\mathrm{Na}$ tela do artista eslavo-brasileiro Miguel Bakun, intitulada Desembocadura (PROLIK, 2009, p. 57), pode-se notar a natureza representada pela poeticidade 
potencializada pelas cores. A obra pictórica interpela de imediato o olhar. Os desenhos e as cores chamam a atenção de forma instantânea. Na tela vê-se uma floresta ao fundo; na parte inferior da tela, um areão e um rio, com duas construções ao centro.

Aos poucos se vão constatando os detalhes presentes na citada pintura: uma figura humana em frente à porta da construção do centro da tela; a pequena janela da construção à direita, o que parece ter a forma e/ou mancha que lembra a silhueta de um pássaro; de uma ave de cor verde que sobrevoa a mata logo acima da primeira construção (ou tal forma é apenas uma mancha que pode significar ainda uma parte mais escura da mata).

Desembocadura atrela homem e natureza. A construção maior que aparece na tela está como que arrebatada e encoberta por algumas formas que podem ser vegetação, nuvens e avançam em direção à casa, já ocultando uma pequena parte desta, tudo isto a envolver a pequena figura humana, que se alinha frente à porta, quase que imperceptível diante da imensidão da natureza que está ao seu redor.

A poética da paisagem desta tela reside nessas ligações todas entre os seres da natureza. Mata, céu e terra têm uma relação simbiótica e concorrem para a organicidade da paisagem. $O$ homem, evidentemente, faz parte dessa relação orgânica; está embrenhado na paisagem, a compõe como peça de algo maior. Mostra que faz parte de um todo e, ao mesmo tempo, realça sua pequenez enquanto sujeito do cosmos. Logo, o visual desta tela, assim como de toda arte pictórica, tende a ser mais imediato, mas não significa erradicar ou sublimar o também aspecto visual da poesia, tampouco a poeticidade presente na pintura, pois se ela instiga, emociona, arrebata, encanta, então tem também poesia, isto é, emana a poeticidade que se encontra presente na variedade das cores e das formas das figuras.

Segundo Praz (1982), a arte do poeta e a arte do pintor, apesar de "mostradas" por diferentes meios de expressão, têm em comum o gosto e a mensagem. Assim, "Aquilo que o pintor transmite numa imagem visual, o poeta comunica numa linguagem que alude vagamente às implicações do cenário natural" (PRAZ, 1982, p. 62). Além disso, a simples apreciação/leitura de uma obra literária e/ou artística já é em si um processo interpretativo. É o encontro de duas sensibilidades, de acordo com Praz (1982), a do sujeito artista e do leitor. 
Toda estimativa estética representa 0 encontro de duas sensibilidades, a sensibilidade do autor da obra de arte e a do intérprete. Aquilo a que chamamos intepretação é, por outras palavras, o resultado da filtragem da expressão de outrem pela nossa própria sensibilidade [...] (PRAZ, 1982, p. 33).

Evidentemente, a filtragem do visual é mais imediata. O verbal necessita de uma filtragem maior para fazer sentido na mente do leitor. Nessa perspectiva, Oliveira observa que "É da natureza da pintura fazer ver. Ela é objeto para os olhos. A poesia é objeto para a mente, mas aspira oferecer-se à visão [...]" (OLIVEIRA, 1999, p. 162).

O olhar abrange a totalidade da pintura e vai, aos poucos, investigando os detalhes: parte do todo para as partes. Na tela de Bakun já mencionada anteriormente, pode-se notar a singela presença humana na natureza. Tal figura localiza-se quase que imperceptível no centro da tela, à porta da casa, minúscula, com uma roupa azul. Num panorama geral da paisagem que a cerca notamos a imensidão natural que a envolve totalmente. Mesmo frente à casa, construção para abrigar-se de intempéries, nota-se a pequenez do homem.

Em primeiro plano, na parte inferior da tela citada, observa-se terra (ou areia) e um pequeno barranco, contornado por um rio, pintado de negro. A cor predominante desta parte inferior é o amarelo e o branco, com algumas nuances de verde. Na parte mais ao centro da tela têm-se, efetivamente, a presença humana: uma casa toda branca com duas janelas e uma porta, pintadas em vermelho, justamente onde se localiza o provável habitante da moradia.

Paralelamente a esta construção central, há, à direita, outra construção menor, com apenas uma janela. Parece tratar-se de uma construção em madeira, provavelmente um depósito (paiol; galpão) utilizado para guardar ferramentas e alimentos (cereais/grãos), já que estes eram e ainda são comuns no interior da região onde nasceu o artista. Em frente às duas construções, há um pequeno descampado, saliente pela cor amarela esverdeada. Os telhados, tanto da casa quanto da outra habitação, na cumeeira, formam um ângulo agudo, fazendo com que o telhado fique bastante inclinado, arquitetura bem típica das casas erguidas pelos europeus no início de seu estabelecimento no estado.

Ainda na parte central de Desembocadura, à esquerda há uma pequena moita (capão) de mato, onde prevalece a cor verde-musgo, com algumas manchas mais claras em amarelo. Ao olhar atentamente essa pequena mancha negra de 
mata, vê-se imediatamente acima dela e da casa, ao centro, transparecer uma massa informe que lembra o formato de um pássaro, voando da esquerda para a direita, ou pode ser, também, o registro de esvoaçante nuvem.

Finalmente, na parte superior, está a grande floresta a encobrir uma montanha, encosta junto à qual foram construídas as habitações. Os tons amarelos marcam a copa das árvores mais altas. Ainda o azul e o verde compõem o cenário dessa parte da mata. Bem ao fundo, há um espaço limitado ao céu. Ele aparece em azul e branco na parte superior direita da tela. É a natureza plena a envolver tudo nesta tela, tendo o rio, as árvores, pássaro e o próprio homem como seres integrantes. A totalidade da pintura faz com que o olho visualize o todo e depois vá observando as partes que formam esse todo.

$\mathrm{Na}$ poesia, esse olhar atua de forma diferente: converge das partes para o todo. Na leitura do poema se vão rastreando os vocábulos, os versos, as estrofes e, por meio de um processo interpretativo, vão se formando imagens do que foi refletido aos olhos. É nesta perspectiva que Oliveira (1999) salienta que a poesia aspira oferecer-se à visão, pois os olhos necessitam correr a página de caracteres verbais para organizar um conjunto e formar imagens e, a partir daí, engendrar significados.

O poema também pode ser ouvido. Se recitado, não há a necessidade dos olhos, mas de todo modo aspira ao visual porque, neste caso, o ouvinte (que pode até fechar os olhos) também vai formando uma imagem mental do que ouve. Nesse sentido é que a poesia se volta também aos seus primórdios, onde era recitada e cantada. É nos primórdios de toda civilização ocidental, na Grécia Antiga, que nascem as primeiras equiparações entre poesia e pintura. Entre os latinos, posteriormente, o pensador Horácio já atentava para essa relação de proximidade entre poesia e pintura ao observar, em seu famoso preceito ut pictura poesis, que

Poesia é como pintura; uma te cativa mais, se te deténs mais perto; outra, se te põe mais longe; esta prefere a penumbra; aquela quererá ser contemplada em plena luz, porque não teme o olhar penetrante do crítico; essa agradou uma vez; essa outra, dez vezes repetida, agradará sempre (HORÁCIO, 1997, p. 65).

Desta consideração de Horácio à atualidade muito se discutiu a respeito da relação poético-plástica, bem como se alargaram infinitamente os estudos comparativos entre essas duas artes. A contemporaneidade se caracteriza pelo forte 
apelo ao visual. As imagens estão presentes em todo lugar: cores e desenhos são utilizados cotidianamente na vida prática das pessoas: cores do semáforo, placas de trânsito, emoticons em redes sociais, orientações em mapas, livros, sinalizações e indicações diversas, etc. Chamam, de imediato, à atenção. Um leitor de um texto verbal leva mais tempo para formar uma imagem do que lê; o que ele vê é instantâneo, o interpela mais facilmente. Essa constante não esvazia, tampouco diminui o valor do texto verbal; ao contrário, este tipo de texto, notadamente o poético, também contém imagens, apenas construídas com outros recursos que não os empregados pela pintura.

[...] uma vez que o poeta não tem o recurso da luz, das cores, do desenho e do signo global imediato, mas em seus versos, usa as metáforas, a adjetivação expressiva, os contrastes e as alegorias, estabelecendo um ritmo poético que o poderá igualar àqueles que com pincéis, traços e cores construíram paisagens e retratos (CORTEZ, 2009, p. 367).

Sem dúvida, quando se lê um texto poético, vão-se construindo imagens na mente. A operação de leitura verbal, pode-se dizer, vai das partes para o todo porque vamos paulatinamente juntando os vocábulos, versos, estrofes para construir o global; assim, tem-se a imagem, segundo sensibilidade particular, do que está ali contido. Quanto ao texto visual, faz-se o movimento oposto, porque há a tendência a observar o global, o conjunto, para depois ir-se observando as particularidades, os detalhes: a cor, as figuras menores em segundo plano que eventualmente possam compor um quadro, as fisionomias, a luminosidade, etc.

Por vezes caracterizadas como arte do tempo (poesia) ou arte do espaço (pintura), essa diferenciação as separa, mas não a tal ponto que ela possa ser totalizadora. Salientando a especificidade de cada uma e, ao mesmo tempo, concordando com a aproximação entre as duas artes, Oliveira assim se expressa:

Não obstante apresentarem leis próprias, apreendendo a composição como um todo, nas artes espaciais, ou completando a experiência com o enunciar da última palavra ou nota, nas temporais, as artes se contemplam e se completam como vasos comunicantes que buscam a totalidade da representação artística (OLIVEIRA, 1999, p. 14).

O autor, apesar de salientar o aspecto temporal da poesia e espacial da pintura, reitera a irmandade entre elas. Ademais, e como ele próprio vai enfatizar, 
algo que as une, invariavelmente, é a imagem, já que as duas artes se organizam de modo a formarem imagens do mundo e do homem. Dessa maneira, ele compactua com a irmandade das artes. Quanto ao poema, observa que o jogo do fazer poético, nas articulações dos vocábulos, alicerça imagens.

Lessing, que caracteriza, como já observado, a poesia como arte das ações no tempo e a pintura como arte dos corpos no espaço, faz também a ressalva de que a primeira não renuncia totalmente ao espaço, enquanto que a segunda não escapa totalmente ao tempo. Nas palavras do autor,

[...] todos os corpos não existem apenas no espaço mas também no tempo. Eles perduram e podem parecer diferentes e se encontrar numa outra relação em cada momento da sua duração. Cada uma dessas aparições momentâneas e relações é o efeito de uma anterior e pode ser a causa de uma sucessiva e, assim, como que o centro de uma ação. Consequentemente a pintura também pode imitar ações, mas apenas alusivamente através de corpos (LESSING, 2011, p. 195).

No tocante à poesia, o crítico alemão tece considerações, ligando a tessitura poética também ao espaço. Se a pintura alude ao tempo e suscita ações por meio de corpos, a poesia, caracterizada pelos signos verbais, não renega totalmente o espaço, pois as ações encadeadas pelos versos dos poemas vão formando imagens de corpos. Dessa maneira, se as ações existem, se perfazem e acontecem no decorrer do tempo,

Por outro lado, as ações não podem existir apenas por si mesmas, mas dependem de certos seres. Na medida em que esses seres são corpos ou são observados como corpos, a poesia também expõe corpos, mas apenas alusivamente através das ações (LESSING, 2011, p. 195).

Esta é a ressalva que Lessing faz em relação à poesia e à pintura, o que também, de certa forma, caracteriza a irmandade entre ambas. A primeira não recusa o espaço, enquanto que a segunda não negligencia totalmente o tempo. Ambas irradiam imagens. Quando se ouve ou se lê um poema, evidentemente não se espera que o texto diga tudo. Muito de seu teor está nas entrelinhas. O poeta não pode contar tudo; inferem-se muitas coisas por meio do linguístico e, a partir dele, pode-se buscar os significados do poema. Recorre-se à imaginação para completálo e dar-Ihe um sentido. De parte em parte o poema se faz no todo. 
O pintor, traçando linhas e pontos no espaço, também não conta tudo porque sua arte, assim como a poética, é apenas uma impressão, um ponto de vista que ele tem do mundo que o cerca. Em ambas há remissão ao tempo e ao espaço, de modo que Lessing as compara a dois vizinhos que têm em comum as fronteiras e se intercomunicam por elas, mas que, no íntimo, ainda se mantêm distantes pelas suas diferentes linguagens. Ambas se intercambiam,

No entanto, assim como dois vizinhos justos e amigos não permitem que o outro tome liberdades inconvenientes no seu domínio mais íntimo, mas decerto permitem que reine uma indulgencia recíproca quanto às fronteiras mais externas que compensa de modo pacífico as pequenas invasões nos direitos um do outro que cada um se vê obrigado a fazer rapidamente premidos pela necessidade: o mesmo se passa entre a pintura e a poesia (LESSING, 2011, p. 213).

São as relações que unem as artes na base e as diferenciam no topo, conforme assinala também Kandinsky, ao observar que "Todas as artes provêm da mesma e única raiz. Logo, todas as artes são idênticas” (KANDINSKY, 2015, p. 256). Semelhantes na origem, diferentes na expressão, poesia e pintura se interligam intimamente. Para descortiná-las deve-se fazer uso de todos os sentidos. Kandinsky assinala a respeito da recepção da pintura com as seguintes palavras: "Não se engane, não pense que 'recebe' a pintura apenas pelos olhos. Não, sem saber, você a recebe pelos cinco sentidos" (KANDINSKY, 2015, p. 258). Esta premissa vale evidentemente também em relação ao processo de criação e se estende para a poesia. O verbal e o visual se interpenetram, e essa relação constituída é constante tanto na arte poética como na pictórica.

Poesia e pintura são atividades que falam das mesmas coisas de modos diferentes. Consideradas as suas particularidades, são meios de registrar a vida do homem, e aproximar essas duas artes constitui um meio de se buscar entender um pouco do humano contido nelas: tanto uma como outra são pontes de diálogos entre os homens.

\section{Considerações finais}

Este trabalho pretendeu registrar algumas considerações acerca da pintura e da poesia e das suas correlações, particularidades e semelhanças, além de argumentar acerca da presença da natureza na obra poética de Helena Kolody e na 
pictórica de Miguel Bakun, salientando como cada artista registrou essa natureza pelos dois distintos sistemas de linguagem. Os signos verbais e visuais acompanham o homem há milênios, de modo que são totalmente necessários e também frutíferos trabalhos que venham a explorar essas duas manifestações artísticas e suas relações.

Os dois referidos artistas nasceram no seio da cultura eslava, a qual se arraigou principalmente nos estados do Sul do Brasil e, especialmente, no estado do Paraná ao final do século XIX e início do século $X X$. Produziram no século $X X$ e foram modernistas no desenvolvimento das respectivas artes: Kolody, por seus versos curtos e poemas sintéticos, uma linguagem fluída e livre de preciosismos vocabulares; Bakun, por seu autodidatismo e falta de formação acadêmica. Dessa maneira, pode-se dizer que os dois artistas, mesmo produzindo de um espaço descentralizado do eixo Rio-São Paulo, podem ser caracterizados pelas inovações salientadas como partícipes involuntários do modernismo brasileiro, que se propunha a inovar nas artes e na literatura, assim como reformular o Brasil estética e ideologicamente.

De outra forma, estudos dessa natureza, ou seja, de traçar comparativos entre literatura e outras artes, bem como estudar escritores e obras literárias e/ou artísticas oriundas de diversos espaços do globo que não aqueles hegemonizados canonicamente, encontram hoje respaldo no campo comparatista, haja vista que as produções artísticas, como fundamentais na vida do homem, se constroem em diversos espaços e se manifestam de diversas maneiras, de modo que é interessante (re)descobrir e resgatar tais obras e autores desses espaços, por vezes desconhecidos. O presente artigo, portanto, compactua dessa perspectiva, pois elenca dois artistas oriundos de um mesmo espaço sócio-histórico e que ainda não haviam sido postos em diálogo.

A presença inconteste da natureza marcada pela simplicidade na obra poética e pictórica de Kolody e Bakun também fala muito desse espaço da qual se originaram. Em suas obras eles retratam os espaços de suas vivências, por onde circularam e lugares que conheceram, portanto são espaços não inventados senão pelos interstícios da linguagem artística. Assim, a natureza presente na obra dos dois artistas eslavos-brasileiros traz elementos, imagens e cenas como fundo de quintais, árvores, o pinheiro Araucária, flores, rios, também o mar e, sutil e implicitamente, o homem agregado a esta natureza, como ser constituinte e orgânico 
que faz parte inconteste desse meio natural representado pela arte.

Em suma, pode-se dizer que Kolody e Bakun resgatam, em suas obras, o elo que vem se perdendo entre homem e natureza, aproximando-os pelas insígnias da arte, talvez a única manifestação que consiga reatar essa dissociação que vem se operando ao longo do tempo - dissociação que aniquila o homem, pois sem a arte a vida se torna tediosa e, por outro lado, sem a natureza o homem sucumbe, pois é um ser orgânico que necessita dessa relação com outros elementos da cadeia natural para sobreviver.

\section{Referências}

BAKUN, Miguel. Desembocadura. s.d. óleo sobre tela $87 \times 72 \mathrm{~cm}$ col. Olga do Rocio Miranda Mariucci. In: PROLIK, Eliane (Org.). Miguel Bakun: a natureza do destino. Textos de Eliane Prolik, Ronaldo Brito, Artur Freitas e Nelson Luz. Curitiba: Edição do autor, 2009.

BOSI, Alfredo. Reflexões sobre a arte. 7. ed. São Paulo: Ática, 2000a. (Fundamentos).

BOSI, Alfredo. O ser e o tempo da poesia. São Paulo: Companhia das Letras, 2000b.

CARVALHAL, Tania Franco. Literatura Comparada. São Paulo: Ática, 1986. (Princípios).

CORTEZ, Clarice Zamorano. Literatura e pintura. In: BONNICI, Thomas; ZOLIN, Lúcia Osana (Org.). Teoria literária: abordagens históricas e tendências contemporâneas. 3. ed. rev. e ampl. Maringá, PR: Eduem, 2009. p. 355-368.

COUTINHO, Eduardo. Sentido e função da Literatura Comparada na América Latina. In: COUTINHO, Eduardo. Literatura Comparada na América Latina: ensaios. Rio de Janeiro: EdUERJ, 2003.

CRUZ, Antonio Donizeti da. O universo imaginário e o fazer poético de Helena Kolody. Cascavel,PR: Edunioeste, 2012.

DA VINCI, Leonardo. Os escritos de Leonardo da Vinci sobre a arte da pintura. CARREIRA, Eduardo (Org.). Brasília: Editora Universidade de Brasília; São Paulo: Imprensa Oficial do Estado, 2000.

HORÁCIO. Arte Poética (Epistula ad Pisones). In: ARISTÓTELES; HORÁCIO; LONGINO. A poética clássica. Introdução por Roberto de Oliveira Brandão; tradução direta do grego e do latim por Jaime Bruna. 7. ed. São Paulo: Cultrix, 1997. p. 5368. 
$\mathbb{B}_{\text {dissel }} \mathfrak{A}$

KANDINSKY, Wassily. Do espiritual na arte e na pintura em particular. Tradução de Álvaro Cabral e Antonio de Pádua Danesi. 3. ed. São Paulo: Martins Fontes, 2015.

KOLODY, Helena. Sinfonia da vida. Tereza Hatue de Rezende (Org.). Curitiba: Letraviva, 1997.

LESSING, Gotthold Ephraim. Laocoonte ou sobre as fronteiras da pintura e da poesia. Introdução, tradução e notas de Márcio Seligmann. São Paulo: lluminuras, 2011.

LOTMAN, luri. A estrutura do texto artístico. Tradução de Maria do Carmo Vieira Raposo e Alberto Raposo. Lisboa: Editorial Estampa, 1978.

MUHANA, Adma. Poesia e Pintura ou Pintura e Poesia: tratado seiscentista de Manuel Pires de Almeida. Tradução do latim de João Ângelo Oliva Neto. São Paulo: Editora da Universidade de São Paulo;Fapesp, 2002.

NITRINI, Sandra. Literatura Comparada: história, teoria e crítica. 3.ed. São Paulo: Editora da Universidade de São Paulo, 2010.

OLIVEIRA, Valdevino Soares de. Poesia e pintura: um diálogo em três dimensões. São Paulo: Fundação editora da UNESP (FEU), 1999.

PAZ, Octavio. Ver e usar: arte e artesanato. In: PAZ, Octavio. Convergências Ensaios sobre arte e literatura. Trad. Moacir Werneck de Castro. Rio de Janeiro: Rocco, 1991. p. 45-57.

PAZ, Octavio. Verso e prosa. In: PAZ, Octavio. Signos em rotação. Tradução de Sebastião Uchoa Leite. 3. ed. São Paulo: Perspectiva, 1996. p. 11-36.

PRAZ, Mário. Literatura e artes visuais. Tradução de José Paulo Paes. São Paulo: Cultrix; Editora da Universidade de São Paulo, 1982.

PROLIK, Eliane (Org.). Miguel Bakun: a natureza do destino. Textos de Eliane Prolik, Ronaldo Brito, Artur Freitas e Nelson Luz. Curitiba: Edição do autor, 2009. 